\section{Morphological and Physiological Responses of Ten Ornamental Taxa to Saline Water Irrigation}

\author{
Qiang Liu ${ }^{1,2}$ \\ Hunan Academy of Forestry, 658 South Shaoshan Road, Changsha, Hunan \\ 410004, China; and the Texas A\&M AgriLife Research Center at El Paso, \\ Texas A\&M University System, 1380 A\&M Circle, El Paso, TX 79927
}

Youping Sun ${ }^{2,3}$

Department of Plants, Soils and Climate, Utah State University, 4820 Old Main Hill, Logan, UT 84322

Genhua Niu ${ }^{2,3}$

Central South University of Forestry and Technology, 498 South Shaoshan Road, Changsha, Hunan 410004, China; and the Texas A\&M AgriLife Research Center at El Paso, Texas A\&M University System, 1380 A\&M Circle, El Paso, TX 79927

\section{James Altland}

USDA-ARS, 1680 Madison Avenue, Wooster, OH 44691

\section{Lifei Chen}

Jilin Agricultural University, 2888 Xincheng Street, Changchun, Jilin 130118, China; and the Texas A\&M AgriLife Research Center at El Paso, Texas A\&M University System, 1380 A\&M Circle, El Paso, TX 79927

\section{Lijuan Jiang \\ Central South University of Forestry and Technology, 498 South Shaoshan Road, Changsha, Hunan 410004, China}

Additional index words: salt tolerance, water reuse, landscape plants

\begin{abstract}
Because of limited supply of high-quality water, alternative water sources have been used for irrigation in water-scarce regions. However, alternative waters usually contain high salt levels, which can cause salt damage on salt-sensitive plants. A greenhouse study was conducted to evaluate the relative salt tolerance of $10 \mathrm{common}$ ornamental taxa to saline water irrigation. The 10 taxa studied were Chaenomeles speciosa 'Orange Storm' and 'Pink Storm' (Chaenomeles Double Take ${ }^{\mathrm{TM}}$ ); Diervilla rivularis 'G2X885411', 'G2X88544' (Diervilla Kodiak ${ }^{\circledR}$, Black, Orange, and Red, respectively), and 'Smndrsf'; Forsythia Xintermedia 'Mindor' $\left(\right.$ Forsythia Show Off $\left.{ }^{\circledR}\right)$; Hibiscus syriacus 'ILVOPS' (Hibiscus Purple Satin ${ }^{\circledR}$ ); Hydrangea macrophylla 'Smhmtau' and 'Smnhmsigma' (Hydrangea Let's Dance ${ }^{\circledR}$ Blue Jangles ${ }^{\circledR}$ and Rave, respectively); and Parthenocissus quinquefolia 'Troki' (Parthenociss quinquefolia Red Wall $\left.^{\circledR}\right)$. Plants were irrigated with a nutrient solution at an electrical conductivity (EC) of $1.2 \mathrm{dS} \cdot \mathrm{m}^{-1}$ (control) or saline solutions at EC of 5.0 or $10.0 \mathrm{dS} \cdot \mathrm{m}^{-1}(\mathrm{EC} 5 \mathrm{or} \mathrm{EC} 10)$ eight times on a weekly basis. The results indicated that the 10 ornamental taxa had different morphological and physiological responses to salinity. The $C$. speciosa and $D$. rivularis plants in EC 5 had severe salt foliar damage, whereas those in EC 10 were dead. Hibiscus syriacus 'ILVOPS' performed well in EC 5 treatment with a shoot dry weight (DW) reduction of $26 \%$, but those in EC 10 had severe foliar salt damage. Hydrangea macrophylla, $F$. Xintermedia 'Mindor' and $P$. quinquefolia 'Troki' were the most salt tolerant with minor foliar salt damage. The two $\mathrm{H}$. macrophylla cultivars had the highest shoot sodium (Na) and chlorine (CI) concentrations with a visual quality of 3 (scale 0 to 5 with 0 for dead plants and 5 for excellent performance), indicating that $\mathrm{H}$. macrophylla plants adapted to elevated salinity by tolerating high $\mathrm{Na}$ and $\mathrm{Cl}$ concentrations in leaf tissue. Forsythia $\times$ intermedia 'Mindor' and $P$. quinquefolia 'Troki' had relatively low leaf $\mathrm{Na}$ and $\mathrm{Cl}$ concentration, indicating that both taxa are capable of excluding $\mathrm{Na}$ and $\mathrm{Cl}$. Chaenomeles speciosa and $D$. rivularis were sensitive to salinity with great growth reduction, severe foliar salt damage, and high $\mathrm{Na}$ and $\mathrm{Cl}$ accumulation in leaf tissue.
\end{abstract}

Use of alternative water sources such as municipal reclaimed water for landscape and

nursery irrigation is of increasing importance (Yeager et al., 2010). Increased population results in increased demand for freshwater. On the other hand, population growth inevitably increases the production of municipal wastewater. Treated municipal wastewater has already been used for irrigation of landscapes and nursery crops in water-scarce regions for decades (Dobrowolski et al., 2008; Morgan et al., 2008; Tanji et al., 2008; Yeager et al., 2010). However, reclaimed water contains higher salt concentrations than potable water, and the elevated salinity can cause salt damage on salt-sensitive plants (Niu and Cabrera, 2010).

Salinity decreases soil water potential and thereby makes water less available to plants (Munns, 2002). Typical plant responses to salinity include stunted plant growth and foliar injury such as leaf edge burn, scorch, necrosis, and premature defoliation (LeCompte et al., 2017; Munns, 2002; Niu and Cabrera, 2010). Salinity may also induce a series of metabolic dysfunctions in plants, including absorption of excessive $\mathrm{Na}$ and $\mathrm{Cl}$, resulting in nutrient imbalance, and inhibition of plant photosynthesis and stomatal conductance $\left(g_{\mathrm{s}}\right)$ (Munns and Tester, 2008). Information on salt tolerance of commonly used landscape plants is still limited.

The 10 ornamental taxa selected for this study are commonly used for commercial and residential landscapes. Chaenomeles speciosa ('Orange Storm' and 'Pink Storm') is a thorny deciduous or semi-evergreen shrub native to eastern Asia. Diervilla rivularis ('G2X885411', 'G2X88544', and 'Smndrsf') is a flowering shrub in the honeysuckle family and native to the eastern United States. Forsythia Xintermedia 'Mindor' is an ornamental deciduous shrub well adapted to temperature changes and is widely planted in gardens and parks. Hibiscus syriacus is a species of flowering plant in the Malvaceae family native to Asia. Hydrangea macrophylla ('Smhmtau' and 'Smnhmsigma') is a species of flowering plant in the family of Hydrangeaceae native to Japan. Parthenocissus quinquefolia, native to eastern and central North America, is a species of flowering plant in the family Vitaceae. The salt tolerance of these taxa is unknown.

To increase the plant selection option for areas where alternative waters may be used for irrigation, evaluation of salt tolerance for popular landscape plants is necessary. The purposes of this study were to compare the relative salt tolerance of the previously described 10 ornamental taxa by quantifying the growth, morphological, and physiological responses to a range of salinity in a greenhouse study.

\section{Materials and Methods}

Plant materials and growing conditions. Rooted cuttings (in $5.7 \mathrm{~cm}$ pots) of 10 ornamental taxa (Table 1) were received from Spring Meadow Nursery Inc. (Grand Haven, MI) on 3 Mar. 2016. On 4 Mar., the cuttings were transplanted into \#1 $(2.7 \mathrm{~L})$ Poly-Tainer containers (No. $1 \mathrm{P}, 16.5 \times 16.5$ $\mathrm{cm}$ ) filled with Metro-Mix 360 RSI [canadian 
Table 1 . Height and shoot dry weight $(\mathrm{DW})$ of 10 ornamental taxa irrigated with nutrient solution [electrical conductivity $\left(\right.$ EC) $=1.2 \mathrm{dS} \cdot \mathrm{m}^{-1}$; Control] or saline solution $\left[\mathrm{EC}=5.0 \mathrm{dS} \cdot \mathrm{m}^{-1}(\mathrm{EC} 5)\right.$ or $\left.10.0 \mathrm{dS} \cdot \mathrm{m}^{-1}(\mathrm{EC} 10)\right]$ in a greenhouse. Plants were harvested after the fourth (first harvest, $5 \mathrm{weeks}$ after initiation of treatment) and eighth treatment (second harvest, 9 weeks after initiation of treatment).

\begin{tabular}{|c|c|c|c|c|c|c|c|c|c|c|c|c|}
\hline \multirow[b]{3}{*}{ Taxa } & \multicolumn{6}{|c|}{$\mathrm{Ht}(\mathrm{cm})$} & \multicolumn{6}{|c|}{ Shoot DW $(\mathrm{g})$} \\
\hline & \multicolumn{3}{|c|}{ First harvest } & \multicolumn{3}{|c|}{ Second harvest } & \multicolumn{3}{|c|}{ First harvest } & \multicolumn{3}{|c|}{ Second harvest } \\
\hline & Control & EC 5 & EC 10 & Control & EC 5 & EC 10 & Control & EC 5 & EC 10 & Control & EC 5 & EC 10 \\
\hline Chaenomeles speciosa 'Orange Storm' & $18.3 \mathrm{a}^{\mathrm{z}}$ & $11.5 \mathrm{~b}$ & $4.4 \mathrm{c}$ & $38.3 \mathrm{a}$ & $24.9 \mathrm{~b}$ & - & $10.4 \mathrm{a}$ & $8.2 \mathrm{~b}$ & $6.6 \mathrm{c}$ & $19.0 \mathrm{a}$ & $8.0 \mathrm{~b}$ & - \\
\hline Chaenomeles speciosa 'Pink Storm' & $18.6 \mathrm{a}$ & $17.2 \mathrm{a}$ & $-\mathrm{y}$ & $34.1 \mathrm{a}$ & $32.1 \mathrm{a}$ & - & $12.9 \mathrm{a}$ & $10.7 \mathrm{~b}$ & $3.9 \mathrm{c}$ & $20.9 \mathrm{a}$ & $7.4 \mathrm{~b}$ & - \\
\hline Diervilla rivularis ' $\mathrm{G} 2 \mathrm{X} 885411$ ' & $12.3 \mathrm{a}$ & $4.9 \mathrm{~b}$ & - & $14.5 \mathrm{a}$ & $4.3 \mathrm{~b}$ & - & $12.7 \mathrm{a}$ & $8.5 \mathrm{~b}$ & $3.0 \mathrm{c}$ & $24.0 \mathrm{a}$ & $7.9 \mathrm{~b}$ & - \\
\hline Diervilla rivularis ' $\mathrm{G} 2 \mathrm{X} 88544$ ' & $23.9 \mathrm{a}$ & $21.3 \mathrm{a}$ & - & $53.4 \mathrm{a}$ & $33.6 \mathrm{~b}$ & - & $16.3 \mathrm{a}$ & $12.5 \mathrm{a}$ & $5.4 \mathrm{~b}$ & $36.5 \mathrm{a}$ & $11.3 \mathrm{~b}$ & - \\
\hline Diervilla rivularis 'Smndrsf' & $26.0 \mathrm{a}$ & $14.9 \mathrm{~b}$ & - & $80.2 \mathrm{a}$ & $13.0 \mathrm{~b}$ & - & $16.5 \mathrm{a}$ & $9.6 \mathrm{~b}$ & $4.3 \mathrm{c}$ & $35.2 \mathrm{a}$ & $6.7 \mathrm{~b}$ & - \\
\hline Forsythia $\times$ intermedia 'Mindor' & $29.5 \mathrm{a}$ & $27.8 \mathrm{a}$ & $16.1 \mathrm{~b}$ & $51.6 \mathrm{a}$ & $40.1 \mathrm{a}$ & $22.9 \mathrm{~b}$ & $16.2 \mathrm{a}$ & $11.3 \mathrm{~b}$ & $8.1 \mathrm{c}$ & $32.1 \mathrm{a}$ & $14.4 \mathrm{~b}$ & $7.1 \mathrm{~b}$ \\
\hline Hibiscus syriacus 'ILVOPS' & $17.6 \mathrm{a}$ & $17.9 \mathrm{a}$ & $14.7 \mathrm{a}$ & $17.8 \mathrm{a}$ & $16.5 \mathrm{a}$ & $13.2 \mathrm{a}$ & $11.3 \mathrm{a}$ & $8.8 \mathrm{a}$ & $4.6 \mathrm{~b}$ & $13.2 \mathrm{a}$ & $9.8 \mathrm{ab}$ & $5.1 \mathrm{~b}$ \\
\hline Hydrangea macrophylla 'Smhmtau' & $6.1 \mathrm{a}$ & $2.1 \mathrm{~b}$ & $1.1 \mathrm{~b}$ & $15.9 \mathrm{a}$ & $6.7 \mathrm{~b}$ & $2.1 \mathrm{c}$ & $16.9 \mathrm{a}$ & $11.3 \mathrm{~b}$ & $9.3 \mathrm{~b}$ & $32.4 \mathrm{a}$ & $14.7 \mathrm{~b}$ & $8.6 \mathrm{~b}$ \\
\hline Hydrangea macrophylla 'Smnhmsigma' & $6.9 \mathrm{a}$ & $3.3 \mathrm{ab}$ & $2 \mathrm{~b}$ & $22.0 \mathrm{a}$ & $5.6 \mathrm{~b}$ & $1.4 \mathrm{c}$ & $15.5 \mathrm{a}$ & $12.5 \mathrm{~b}$ & $10.3 \mathrm{c}$ & $35.7 \mathrm{a}$ & $13.2 \mathrm{~b}$ & $8.7 \mathrm{c}$ \\
\hline Parthenocissus quinquefolia 'Troki' & $139.2 \mathrm{a}$ & $114.5 \mathrm{a}$ & $68.4 \mathrm{~b}$ & $223.7 \mathrm{a}$ & $117.9 \mathrm{~b}$ & $76.7 \mathrm{c}$ & $18.5 \mathrm{a}$ & $13.1 \mathrm{~b}$ & $9.4 \mathrm{c}$ & $43.1 \mathrm{a}$ & $21.7 \mathrm{~b}$ & $5.9 \mathrm{c}$ \\
\hline
\end{tabular}

${ }^{\mathrm{z}}$ Means with same letters within a row and harvest date are not significantly different among treatments by Tukey's honestly significant difference or (when all plants in one of the three treatments died) with a Student's $t$ test at $P<0.05$.

${ }^{\mathrm{y}}$ All plants were dead.

sphagnum peatmoss $45 \%$ to $55 \%$, vermiculite, composted bark, dolomite limestone, and $0.0001 \%$ silicon dioxide $\left(\mathrm{SiO}_{2}\right)$; SunGro Hort., Bellevue, WA]. All plants were grown in a greenhouse in El Paso, TX (lat. $31^{\circ} 41^{\prime} 45^{\prime \prime} \mathrm{N}$, long. $106^{\circ} 16^{\prime} 54^{\prime \prime} \mathrm{W}$, elev. $1139 \mathrm{~m}$ ) and well irrigated with reverse osmosis (RO) waterbased nutrient solution to avoid salt accumulation in the root zone until treatments started. Two weeks after transplanting (17 Mar.), uniform plants were chosen and treatments were started. The average air temperature in the greenhouse was $25.6 \pm$ $4.2{ }^{\circ} \mathrm{C}$ during the day and $17.2 \pm 4.2{ }^{\circ} \mathrm{C}$ at night. The average daily light integral was $9.5 \pm 1.9 \mathrm{~mol} \cdot \mathrm{m}^{-2} \cdot \mathrm{d}^{-1}$ and the average relative humidity was $34.7 \% \pm 13.0 \%$ during the experiment.

Treatments. A nutrient solution at an EC of $1.2 \mathrm{dS} \cdot \mathrm{m}^{-1}$ was used as the control. The nutrient solution was prepared by adding 1 g. $\mathrm{L}^{-1} 15 \mathrm{~N}-2.2 \mathrm{P}-12.5 \mathrm{~K}$ (Peters 15-5-15 CalMag Special; Scotts, Marysville, $\mathrm{OH}$ ) to RO water. Saline solutions at an EC of $5.0 \mathrm{dS} \cdot \mathrm{m}^{-1}$ (EC 5) was prepared by adding $1.20 \mathrm{~g} \cdot \mathrm{L}^{-1}$ sodium chloride $(\mathrm{NaCl})$ and $1.16 \mathrm{~g} \cdot \mathrm{L}^{-1}$ cal-

\footnotetext{
This research is partially supported by a Specific Cooperative Agreement from Agricultural Research Service (ARS), Department of Agriculture (USDA), the USDA National Institute of Food and Agriculture Hatch project TEX090450, and Texas A\&M AgriLife Research. The content is solely the responsibility of the authors and does not necessarily represent the official views of the funding agencies. The authors appreciate the financial support from China Scholarship Council to Qiang Liu as a visiting graduate student and Lifei Chen as a visiting scholar at Texas A\&M AgriLife Research Center at El Paso, TX, and the in-kind support of plant materials from Spring Meadow Nursery Inc. (Grand Haven, MI). The authors also thank Douglas Sturtz at USDA-ARS for his help in mineral analysis.

${ }^{1}$ This author was a Ph.D. student from China and co-supervised by Genhua Niu and his home institution advisor in China, Lijuan Jiang, and his advisor is therefore a coauthor of this article. ${ }^{2}$ These authors contributed equally to this paper. ${ }^{3}$ Corresponding authors. E-mail: youping.sun@ usu.edu orgniu@ag.tamu.edu.
}

cium chloride $\left(\mathrm{CaCl}_{2}\right)$ to the nutrient solution and saline solutions at $10.0 \mathrm{dS} \cdot \mathrm{m}^{-1}$ (EC 10) was prepared by adding $2.84 \mathrm{~g} \cdot \mathrm{L}^{-1} \mathrm{NaCl}$ and $2.70 \mathrm{~g} \cdot \mathrm{L}^{-1} \mathrm{CaCl}_{2}$ to the nutrient solution. The $\mathrm{pH}$ of all solutions was adjusted to 6.6. Both nutrient and saline solutions were prepared in 100-L tanks with confirmed EC using an EC meter (Model B173; Horiba, Ltd., Kyoto, Japan) before irrigation.

From 17 Mar. to 20 May, treatment solutions were applied once a week, eight times in total. At each irrigation, plants were irrigated with $1 \mathrm{~L}$ treatment solution per plant, resulting in a leaching fraction of $\approx 25 \%$. Between the treatment solution irrigations, plants were irrigated with nutrient solution whenever substrate surface became dry. Irrigation frequency varied with environmental conditions and treatment. At higher salinity, plants use less water, and thus, less irrigation was needed.

Leachate EC. The leachate EC was determined following the pour-through methods according to Cavins et al. (2008) and Wright (1986). One plant per treatment per taxon was chosen for measurement after treatment solution was applied. Leachate EC readings across taxa were pooled.

Plant growth. Plant height $(\mathrm{cm})$, from the pot rim to the top growth point, was recorded at the beginning of the experiment and on 20 Apr. (first harvest) and on 20 May (second harvest). At both harvest times, aboveground parts of five plants were harvested and shoot DW was determined after oven-drying at $70{ }^{\circ} \mathrm{C}$ for $4 \mathrm{~d}$. Leaf area of all living plants was determined using LI-3100C area meter (LI-COR ${ }^{\circledR}$ Biosciences, Lincoln, NE).

Foliar salt damage evaluation. Foliar salt damage was rated by giving a visual score based on a reference scale from 0 to 5 , where $0=$ dead; $1=$ more than $90 \%$ foliar damage (salt damage: leaf edge burn, necrosis, and discoloration); $2=$ moderate $(50 \%$ to $90 \%)$ foliar damage; 3 = slight (less than 50\%) foliar damage; $4=$ good quality with minimal foliar damage; and $5=$ excellent with no foliar damage (Cai et al., 2014). The foliar salt damage rating did not consider plant size.
Gas exchange. Leaf net photosynthesis $\left(P_{\mathrm{n}}\right)$, transpiration $(\mathrm{E})$, and $g_{\mathrm{s}}$ of four plants per taxon per treatment were measured at the end of the experiment (on 20 Apr. and 20 May) using a CIRAS-2 portable photosynthesis system (PP Systems, Amesbury, MA) with an automatic universal PLC6 broad leaf cuvette. The fully expanded leaf at the top of the plant was chosen for the measurements. The environmental conditions within the cuvette were maintained at a leaf temperature of $25^{\circ} \mathrm{C}$, photosynthetic photon flux of 1000 $\mu \mathrm{mol} \cdot \mathrm{m}^{-2} \cdot \mathrm{s}^{-1}$, and $\mathrm{CO}_{2}$ concentration of 375 $\mu \mathrm{mol} \cdot \mathrm{mol}^{-1}$. Data were recorded when the environmental conditions and gas exchange rates in the cuvette became stable. These measurements were taken on sunny days between 1000 and $1400 \mathrm{HR}$ and plants were well watered the day before to avoid water stress.

Leaf greenness and chlorophyll fluorescence. Leaf greenness (or relative chlorophyll content, SPAD reading) was measured using a handheld chlorophyll meter (measured as the optical density; Minolta Camera Co., Osaka, Japan) 1 week before the first and second harvest. Healthy and fully expanded leaves in the middle of the shoot of five plants were chosen for measurements. Meanwhile, to examine the effect of elevated salinity on leaf photosynthetic apparatus, minimal florescence $\left(F_{0}\right)$, maximum fluorescence $\left(F_{\mathrm{m}}\right)$, and the maximal photochemical efficiency of photosystem II (PSII) [variable fluorescence $\left.\left(F_{\mathrm{v}}\right) / F_{\mathrm{m}}, F_{\mathrm{v}}=F_{\mathrm{m}}-F_{0}\right]$ were measured using a Pocket PEA chlorophyll fluorescence system (Hansatech, Norfolk, UK).

Mineral analysis. To analyze leaf $\mathrm{Na}$, chloride $(\mathrm{Cl})$, potassium $(\mathrm{K})$, and calcium (Ca) concentrations, four samples per treatment per taxon were randomly selected from the first harvest. Dried tissue was ground to pass a 40-mesh screen with a stainless Wiley Mill (Thomas Scientific, Swedesboro, NJ). Dried tissue samples were extracted with $2 \%$ acetic acid (EM Science, Gibbstown, HJ) to determine $\mathrm{Cl}$ using the method described in Gavlak et al. (1994). The concentration of $\mathrm{Cl}$ was determined with a M926 Chloride 
Analyzer (Cole Parmer Instrument Company, Vernon Hills, IL). Dried tissue samples were submitted to the laboratory at USDAAgricultural Research Service (Toledo, $\mathrm{OH}$ ) for analysis of foliar $\mathrm{Na}, \mathrm{Ca}$, and $\mathrm{K}$. In brief, dried tissue samples were digested in nitric acid following the protocol described by Havlin and Soltanpour (1989). Na, K, and $\mathrm{Ca}$ in digested samples were analyzed by inductively coupled plasma-optical emission spectrometry (iCAP 6300 Duo View ICP-OES Spectrometer; Thermo Fisher Scientific, Walthan, MA) and reported on a dry biomass basis as described by Isaac and Johnson (1975).

Experimental design and statistical analysis. The experiment used a split-plot design with the salinity treatment as the main plot and 10 taxa as the subplot with five replications for each harvest per treatment per taxon. For growth, gas exchange, and relative chlorophyll content (SPAD readings), there were five replications. For mineral analysis, there were four replications; for measurement of chlorophyll fluorescence and weekly leachate, there were three replications. A two-way analysis of variance was used to test the effects of salinity and taxon on plant growth. Means separation among treatments was conducted using Tukey's honestly significant difference multiple comparison, when all plants in one of the three treatments died, a Student's $t$ test was used at $P<0.05$.

Hierarchical cluster analysis was conducted based on Ward linkage method and squared Euclidian distance on the means of the main salt tolerance indices (Zeng et al., 2002), including relative values of height, DW, and visual score data (Wu et al., 2016a). All statistical analyses were performed using JMP (Version 12; SAS Institute Inc., Cary, $\mathrm{NC)}$.

\section{Results and Discussion}

Leachate EC. The average leachate EC of control solution treatment ranged from 2.6 to $4.9 \mathrm{dS} \cdot \mathrm{m}^{-1}$ during the experiment (Fig. 1). For EC 5 and EC 10, the leachate EC increased from 4.9 to $10.3 \mathrm{dS} \cdot \mathrm{m}^{-1}$, and from 7.0 to $17.3 \mathrm{dS} \cdot \mathrm{m}^{-1}$, respectively. The results revealed that the salinity of medium leachate was much higher than that of irrigation solution. The leachate EC increased as the salinity level and irrigation frequency increased. Similar results were reported in other comparable studies (Niu and Rodriguez, 2006; Wu et al., 2016a, 2016b). Peatmoss is a common component in potting mix for nursery crop and has higher cation exchange capacity than pine bark (Altland et al., 2014), and thus salt accumulates. Therefore, when reporting salinity, the root zone EC should be provided (Niu and Cabrera, 2010). Some studies used inert substrate such as perlite or growing plants hydroponically may minimize the fluctuation of root zone salinity (Bernstein et al., 2006). For long-term crop production in containers, a substrate with lower percent-

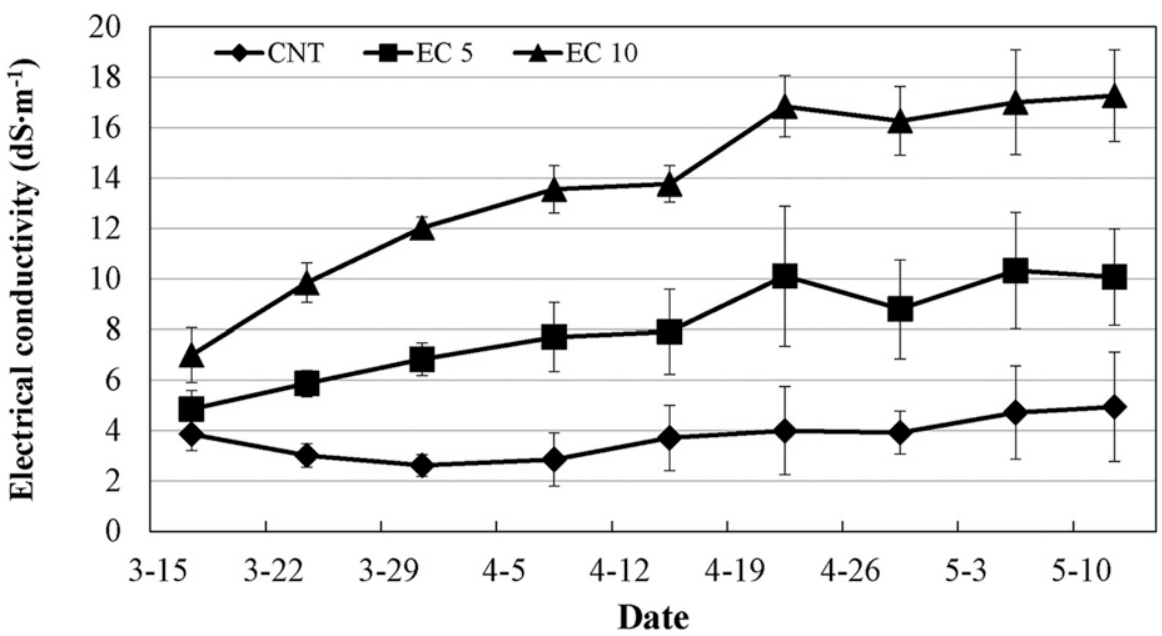

Fig. 1. Time course of the weekly leachate electrical conductivity (EC) during an experimental period. Control (CNT) represents nutrient solution at an EC of $1.2 \mathrm{dS} \cdot \mathrm{m}^{-1}$; EC 5 represents saline solution at an EC of $5.0 \mathrm{dS} \cdot \mathrm{m}^{-1}$; and EC 10 represents saline solution at an EC of $10.0 \mathrm{dS} \cdot \mathrm{m}^{-1}$. All plants were watered with the nutrient solution on 12 May. Vertical bars represent standard errors of 10 measurements, one per taxon.

age of peatmoss should be used to prevent salt accumulation.

Plant growth and visual score. Compared with control $\left(1.2 \mathrm{dS} \cdot \mathrm{m}^{-1}\right)$, EC 5 decreased the height of C. speciosa 'Orange Storm', D. rivularis 'Smndrsf' and 'G2X885411', and H. macrophylla 'Smhmtau' at the first harvest ( 5 weeks after treatment initiation) in the order of low to high, from $37 \%$ to $66 \%$ (Table 1). Treatment EC 5 also decreased the height of all tested taxa at the second harvest ( 9 weeks after treatment initiation) except for C. speciosa 'Pink Storm', F. xintermedia 'Mindor', and $H$. syriacus 'ILVOPS'. All plants of C. speciosa 'Pink Storm', D. rivularis 'G2X885411', 'G2X88544', and 'Smndrsf' died in EC 10 at the first and second harvest and all plants of $C$. speciosa 'Orange Storm' died in EC 10 at the second harvest. These results suggested that these two taxa (C. speciosa and D. rivularis) were sensitive to salinity. Salt treatment did not impact the growth of $H$. syriacus 'ILVOPS'. But $F$. $\times$ intermedia 'Mindor', H. macrophylla 'Smhmtau' and 'Smnhmsigma', and P. quinquefolia 'Troki' in EC 10 had relative height reductions of $45 \%, 82 \%, 71 \%$, and $51 \%$ at the first harvest and $56 \%, 87 \%, 94 \%$, and $66 \%$ at the second harvest, respectively.

The shoot DW of all taxa in EC 5 was reduced compared with control at the first harvest except for D. rivularis 'G2X88544' and $H$. syriacus 'ILVOPS'. At the second harvest, $H$. syriacus 'ILVOPS' was the only taxa that was unaffected by saline solution with the least shoot DW reduction of $26 \%$ in EC 5 compared with control. With EC 10, all taxa had significant reduction of shoot DW from $34 \%$ to $76 \%$ at the first harvest and $61 \%$ to $86 \%$ at the second harvest. The lowest shoot DW reduction $(34 \%)$ was found in $H$. macrophylla 'Smnhmsigma' between EC 10 and control at the first harvest.

Compared with control, saline solution at EC 5 and EC 10 did not reduce the leaf area of
H. syriacus 'ILVOPS' throughout the experiment, except those plants in EC 10 at the second harvest (Table 2). Treatment EC 5 did not significantly reduce the leaf area of $C$. speciosa 'Pink Storm', D. rivularis 'G2X88544', $F$. xintermedia 'Mindor', and H. macrophylla 'Smnhmsigma' at the first harvest, however, all the leaf areas were reduced at the second harvest. In addition, leaf area of all tested taxa was reduced at EC 10.

Severe foliar salt damage such as leaf burn and necrosis was observed on $C$. speciosa 'Orange Storm' and 'Pink Storm' and D. rivularis 'G2X885411', 'G2X88544', and 'Smndrsf' in EC 5, and all died in EC 10 (Table 2). Four taxa including $F$. Xintermedia 'Mindor', $H$. syriacus 'ILVOPS', and $H$. macrophylla 'Smhmtau' and 'Smnhmsigma' were still of good quality in EC 5 with an average visual score greater than 4 at both harvests. Plants of $F$. Xintermedia 'Mindor' and H. macrophylla 'Smhmtau' and 'Smnhmsigma' experienced slight foliar salt damage with mean visual scores of 3 in EC 10 at both harvests. Although H. syriacus 'ILVOPS' had slight foliar salt damage in EC 10 at the first harvest, severe foliar salt damage such ass leaf burn, necrosis, and discoloration exhibited in EC 10 at the second harvest and only one of five plants survived. All P. quinquefolia 'Troki' plants in EC 5 and EC 10 had minimal foliar salt damage at both harvests.

For ornamental plants, maintaining aesthetical appearance is important when irrigated with low-quality water. Therefore, foliar salt damage such as tip burn, leafmargin burn, necrosis, and discoloration has been taken into consideration when assessing salt tolerance of ornamental plants (Cai et al., 2014; Niu et al., 2012; Zollinger et al., 2007). Based on this criterion, $F$. Xintermedia 'Mindor', P. quinquefolia 'Troki', and the two $H$. macrophylla cultivars were more tolerant to salinity, followed by $H$. syriacus 
Table 2. Leaf area and visual score of 10 ornamental taxa irrigated with nutrient solution [electrical conductivity $(\mathrm{EC})=1.2 \mathrm{dS} \cdot \mathrm{m}^{-1}$; Control] or saline solution [EC $=5.0 \mathrm{dS} \cdot \mathrm{m}^{-1}(\mathrm{EC} 5)$ or $10.0 \mathrm{dS} \cdot \mathrm{m}^{-1}$ (EC 10)] in a greenhouse. Plants were harvested after the fourth (first harvest, $5 \mathrm{weeks}$ after initiation of treatment) and eighth treatment (second harvest, 9 weeks after initiation of treatment).

\begin{tabular}{|c|c|c|c|c|c|c|c|c|c|c|c|c|}
\hline \multirow[b]{3}{*}{ Taxa } & \multicolumn{6}{|c|}{ Leaf area $\left(\mathrm{cm}^{2}\right)$} & \multicolumn{6}{|c|}{ Visual score } \\
\hline & \multicolumn{3}{|c|}{ First harvest } & \multicolumn{3}{|c|}{ Second harvest } & \multicolumn{3}{|c|}{ First harvest } & \multicolumn{3}{|c|}{ Second harvest } \\
\hline & Control & EC 5 & $\mathrm{EC} 10$ & Control & EC 5 & EC 10 & Control & EC 5 & $\mathrm{EC} 10$ & Control & EC 5 & EC 10 \\
\hline Chaenomeles speciosa 'Orange Storm' & $564 a^{z}$ & $413 \mathrm{~b}$ & $150 \mathrm{c}$ & $1,442 \mathrm{a}$ & $434 \mathrm{~b}$ & - & $5 \mathrm{a}$ & $2.5 \mathrm{~b}$ & $1.4 \mathrm{c}$ & $5 \mathrm{a}$ & $2.8 \mathrm{~b}$ & $0 \mathrm{c}$ \\
\hline Chaenomeles speciosa 'Pink Storm' & $873 \mathrm{a}$ & $778 \mathrm{a}$ & $-\mathrm{y}$ & $1,536 \mathrm{a}$ & $423 \mathrm{~b}$ & - & $5 \mathrm{a}$ & $2.1 \mathrm{~b}$ & $0 \mathrm{c}$ & $5 \mathrm{a}$ & $2 \mathrm{~b}$ & $0 \mathrm{c}$ \\
\hline Diervilla rivularis 'G2X885411' & $1,257 \mathrm{a}$ & $583 \mathrm{~b}$ & - & $3,791 \mathrm{a}$ & $165 \mathrm{~b}$ & - & $5 \mathrm{a}$ & $3.1 \mathrm{~b}$ & $0 \mathrm{c}$ & $5 \mathrm{a}$ & $1.4 \mathrm{~b}$ & $0 \mathrm{c}$ \\
\hline Diervilla rivularis 'G2X88544' & $2,364 \mathrm{a}$ & $1,555 \mathrm{a}$ & - & 57,778 a & $318 \mathrm{~b}$ & - & $5 \mathrm{a}$ & $3.1 \mathrm{~b}$ & $0 \mathrm{c}$ & $5 \mathrm{a}$ & $1.8 \mathrm{~b}$ & $0 \mathrm{c}$ \\
\hline Diervilla rivularis 'Smndrsf' & $2,033 \mathrm{a}$ & $826 \mathrm{~b}$ & - & $4,438 \mathrm{a}$ & $15.4 \mathrm{~b}$ & - & $5 \mathrm{a}$ & $3.5 \mathrm{~b}$ & $0 \mathrm{c}$ & $5 \mathrm{a}$ & $0.2 \mathrm{~b}$ & $0 \mathrm{c}$ \\
\hline Forsythia $\times$ intermedia 'Mindor' & $1,550 \mathrm{a}$ & $796 \mathrm{a}$ & $390 \mathrm{~b}$ & $2,793 \mathrm{a}$ & $1,159 \mathrm{~b}$ & $289 \mathrm{~b}$ & $5 \mathrm{a}$ & $4.3 \mathrm{ab}$ & $3.6 \mathrm{~b}$ & $5 \mathrm{a}$ & $4.4 \mathrm{a}$ & $2.4 \mathrm{~b}$ \\
\hline Hibiscus syriacus 'ILVOPS' & $719 \mathrm{a}$ & $632 \mathrm{a}$ & 404 a & $584 \mathrm{a}$ & $538 \mathrm{a}$ & $172 \mathrm{~b}$ & $5 \mathrm{a}$ & $4.4 \mathrm{a}$ & $3.3 \mathrm{~b}$ & $5 \mathrm{a}$ & $4.4 \mathrm{a}$ & $0.6 \mathrm{~b}$ \\
\hline Hydrangea macrophylla 'Smhmtau' & $2,193 \mathrm{a}$ & $1,019 \mathrm{~b}$ & $567 \mathrm{~b}$ & $3,945 \mathrm{a}$ & $1,668 \mathrm{~b}$ & $566 \mathrm{c}$ & $5 \mathrm{a}$ & $4.5 \mathrm{a}$ & $3.9 \mathrm{~b}$ & $5 \mathrm{a}$ & $4 \mathrm{~b}$ & $3 \mathrm{c}$ \\
\hline Hydrangea macrophylla 'Smnhmsigma' & $1,659 \mathrm{a}$ & $1,179 \mathrm{ab}$ & $805 \mathrm{~b}$ & $4,431 \mathrm{a}$ & $1,370 \mathrm{~b}$ & $518 \mathrm{c}$ & $5 \mathrm{a}$ & $4.4 \mathrm{~b}$ & $4.2 \mathrm{~b}$ & $5 \mathrm{a}$ & $3.8 \mathrm{~b}$ & $3 \mathrm{~b}$ \\
\hline Parthenocissus quinquefolia 'Troki' & $2,272 \mathrm{a}$ & $1,488 \mathrm{~b}$ & $850 \mathrm{c}$ & $4,743 \mathrm{a}$ & $2,601 \mathrm{~b}$ & $600 \mathrm{c}$ & $5 \mathrm{a}$ & $5 \mathrm{a}$ & $4.9 \mathrm{a}$ & $5 \mathrm{a}$ & $4.8 \mathrm{a}$ & $3.2 \mathrm{a}$ \\
\hline
\end{tabular}

${ }^{\mathrm{z}}$ Means with same letters within a row and harvest date are not significantly different among treatments by Tukey's honestly significant difference or (when all plants in one of the three treatments died) with a Student's $t$ test at $P<0.05$.

${ }^{\mathrm{y}}$ All plants were dead.

'ILVOPS', whereas both C. speciosa and $D$. rivularis cultivars were sensitive to salinity.

Chlorophyll fluorescence. For the first harvest, no significant difference in $F_{\mathrm{v}} / F_{\mathrm{m}}$ was observed between control and EC 5 in all taxa except for $D$. rivularis 'Smndrsf' (Table 3 ). Treatment EC 10 decreased $F_{\mathrm{v}} / F_{\mathrm{m}}$ in H. syriacus 'ILVOPS' and H. macrophylla 'Smhmtau' and 'Smnhmsigma'. For the second harvest, EC 5 reduced $F_{\mathrm{v}} / F_{\mathrm{m}}$ in the remaining surviving plants of $D$. rivularis and $H$. macrophylla 'Smhmtau'. The effects of EC 10 on $F_{\mathrm{v}} / F_{\mathrm{m}}$ were similar to those at the first harvest.

Chlorophyll fluorescence has been offered as a potentially quick, reliable, and inexpensive procedure to detect the differences of ornamental plants in response to salinity (Percival, 2005). The maximal photochemical efficiency of PSII, the ratio of $F_{\mathrm{v}}$ to $F_{\mathrm{m}}, F_{\mathrm{v}} / F_{\mathrm{m}}$, is commonly measured to examine damage in the photosynthetic apparatus caused by salinity stress (Percival, 2005; Sixto et al., 2006). Many studies revealed that the response of chlorophyll fluorescence to salinity varied with plant species and salinity level. For example, salinity of irrigation water did not influence $F_{\mathrm{v}} / F_{\mathrm{m}}$ of the six Lamiaceae ornamental species (Wu et al., 2016b) and Suaeda salsa (Lu et al., 2003). In this experiment, among the survived plants, there were either no or small difference in $F_{\mathrm{v}} / F_{\mathrm{m}}$, such as the saltsensitive $C$. speciosa 'Orange Storm' and 'Pink Storm' and the salt-tolerant $P$. quinquefolia 'Troki', where no differences were found between the control and EC 5. Therefore, it would be difficult to assess the salt tolerance relying solely on $F_{\mathrm{v}} / F_{\mathrm{m}}$ in these taxa.

Relative chlorophyll content (SPAD). Relative chlorophyll contents of all C. speciosa and D. rivularis plants in EC 5 and EC 10 were lower than that of the control (Table 4). At the first harvest, $F$. xintermedia 'Mindor' and P. quinquefolia 'Troki' plants had similar relative chlorophyll content among treatments. Treatment EC 5 did not affect the relative chlorophyll content of
H. syriacus 'ILVOPS' but EC 10 did. In addition, both EC 5 and EC 10 decreased the relative chlorophyll content of $\mathrm{H}$. macrophylla 'Smhmtau' and 'Smnhmsigma'. At the second harvest, the relative chlorophyll content of $H$. syriacus 'ILVOPS', H. macrophylla 'Smhmtau' and 'Smnhmsigma', and $P$. quinquefolia 'Troki' plants in EC 5 were not significantly different from that of the control. Treatment EC 10 reduced the relative chlorophyll content of all survived plants except $H$. macrophylla 'Smnhmsigma'.

Foliar SPAD readings have been used as a reference index for evaluating salt tolerance of plants (Niu and Cabrera, 2010). In a number of herbaceous and woody landscape plants, the relative chlorophyll content of less salt-tolerant species were found significantly reduced with increasing salinity stress (Cabrera, 2009; Niu et al., 2007). In the present study, the sensitive species $C$. speciosa and D. rivularis had greater reduction in relative chlorophyll content.

Leaf gas exchange. At the first harvest, no significant reductions were found between control and EC 5 in E, $g_{\mathrm{s}}$ and $P_{\mathrm{n}}$ for C. speciosa 'Orange Storm', D. rivularis ' $\mathrm{G} 2 \mathrm{X} 88544$ ' and 'Smndrsf', $F$. Xintermedia 'Mindor', $H$. macrophylla 'Smnhmsigma', and P. quinquefolia 'Troki' (Tables 4 and 5). Treatment EC 10 significantly reduced the $\mathrm{E}, g_{\mathrm{s}}$, and $P_{\mathrm{n}}$ of all taxa.

At the second harvest, EC 5 did not reduce the E of C. speciosa 'Orange Storm', Hibiscus syriacus 'ILVOPS', H. macrophylla 'Smnhmsigma', and $P$. quinquefolia 'Troki', whereas EC 10 reduced the E of all taxa except $H$. macrophylla 'Smnhmsigma'. For $g_{\mathrm{s}}$, C. speciosa 'Orange Storm' and $P$. quinquefolia 'Troki' plants in EC 5 were similar to those in control. Both EC 5 and EC 10 treatments did not affect $g_{\mathrm{s}}$ of $H$. macrophylla 'Smnhmsigma'. In addition, Both EC 5 and EC 10 treatments reduced the $P_{\mathrm{n}}$ of all taxa except $C$. speciosa 'Orange Storm', $F$. xintermedia 'Mindor', and P. quinquefolia 'Troki' in EC 5.

The effect of salinity on leaf gas exchange depends on many factors such as taxa, salin- ity level, and duration of salinity stress exposure (Niu and Cabrera, 2010). Differences in gas exchange rates between the control and salinity treatments became greater over time in Phillyrea latifolia (Tattini et al., 2002). Generally, salt-tolerant taxa have higher gas exchanges under the same salinity levels than less-tolerant taxa. In this study, higher salinity treatment EC 10 had greater impact than that of EC 5 and the negative impact was greater in the second harvest. Because of the nature of instantaneous measurement of a single leaf, gas exchange rates sometime may not accurately reflect the whole plant response and long-term effect of salinity. Eventually, accumulative biomass over the treatment period would be the most reliable parameter to assess the impact of salinity.

Mineral analysis. Elevated salinity increased the concentrations of $\mathrm{Na}$ and $\mathrm{Cl}$ in leaf tissue of all taxa compared with the control (Table 6). Treatment EC 5 increased the leaf Na concentration of $C$. speciosa 'Pink Storm', D. rivularis 'G2X88544', H. macrophylla 'Smhmtau' and 'Smnhmsigma', and P. quinquefolia 'Troki' plants by $32,23,22$, 14 , and 11 times, respectively. No statistical difference between EC 5 and control treatment were found in leaf $\mathrm{Na}$ concentration of C. speciosa 'Orange Storm', D. rivularis 'G2X885411' and 'Smndrsf', $F$. Xintermedia 'Mindor', and H. syriacus 'ILVOPS'. Treatment EC 10 increased the leaf Na concentration of all tested plants. The highest $\mathrm{Na}$ concentration ( $\left.15.1 \mathrm{mg} \cdot \mathrm{g}^{-1} \mathrm{DW}\right)$ among taxa was found in H. macrophylla 'Smnhmsigma', whereas the lowest $\mathrm{Na}$ concentration was found in F. xintermedia 'Mindor' (1.91 mg.g $\left.{ }^{-1} \mathrm{DW}\right)$. Compared with their respective control, salt treatment increased leaf $\mathrm{Cl}$ concentrations in both EC 5 (from 10 to 45 times) and EC 10 (from 19 to 103 times). The highest $\mathrm{Cl}$ concentration ( $83.8 \mathrm{mg} \cdot \mathrm{g}^{-1} \mathrm{DW}$ ) among taxa was found in $H$. syriacus 'ILVOPS' in EC 10 , whereas the lowest $\mathrm{Cl}$ concentration (29.3 mg. $\mathrm{g}^{-1} \mathrm{DW}$ ) was found in P. quinquefolia 'Troki' in EC 10.

Salinity did not change the leaf $\mathrm{K}$ concentration in C. speciosa 'Orange Storm', two 
Table 3. The maximal photochemical efficiency of photosystem II $\left(F_{\mathrm{v}} / F_{\mathrm{m}}\right)$ of 10 ornamental taxa irrigated with nutrient solution [electrical conductivity $(\mathrm{EC})=$ $1.2 \mathrm{dS} \cdot \mathrm{m}^{-1}$; Control] or saline solution $\left[\mathrm{EC}=5.0 \mathrm{dS} \cdot \mathrm{m}^{-1}(\mathrm{EC} 5)\right.$ or $10.0 \mathrm{dS} \cdot \mathrm{m}^{-1}$ (EC 10)] in a greenhouse. Plants were harvested after the fourth (first harvest, 5 weeks after initiation of treatment) and eighth treatment (second harvest, 9 weeks after initiation of treatment).

\begin{tabular}{|c|c|c|c|c|c|c|}
\hline \multirow{2}{*}{ Taxa } & \multicolumn{6}{|c|}{$F_{\mathrm{v}} / F_{\mathrm{m}}$} \\
\hline & \multicolumn{3}{|c|}{ First harvest } & \multicolumn{3}{|c|}{ Second harvest } \\
\hline Chaenomeles speciosa 'Orange Storm' & $0.81 \mathrm{a}^{\mathrm{z}}$ & $0.79 \mathrm{a}$ & $0.78 \mathrm{a}$ & $0.81 \mathrm{a}$ & $0.80 \mathrm{a}$ & - \\
\hline Diervilla rivularis 'G2X885411' & $0.80 \mathrm{a}$ & $0.79 \mathrm{a}$ & - & $0.79 \mathrm{a}$ & $0.74 \mathrm{~b}$ & - \\
\hline Diervilla rivularis 'G2X88544' & $0.81 \mathrm{a}$ & $0.79 \mathrm{a}$ & - & $0.81 \mathrm{a}$ & $0.73 \mathrm{~b}$ & - \\
\hline Diervilla rivularis 'Smndrsf' & $0.81 \mathrm{a}$ & $0.77 \mathrm{~b}$ & - & - & - & - \\
\hline Forsythia ×intermedia 'Mindor' & $0.82 \mathrm{a}$ & $0.82 \mathrm{a}$ & $0.79 \mathrm{a}$ & $0.81 \mathrm{a}$ & $0.76 \mathrm{a}$ & $0.69 \mathrm{a}$ \\
\hline Hydrangea macrophylla 'Smnhmsigma' & $0.77 \mathrm{a}$ & $0.75 \mathrm{a}$ & $0.68 \mathrm{~b}$ & $0.77 \mathrm{a}$ & $0.75 \mathrm{ab}$ & $0.63 \mathrm{~b}$ \\
\hline Parthenocissus quinquefolia 'Troki' & $0.80 \mathrm{a}$ & $0.81 \mathrm{a}$ & $0.80 \mathrm{a}$ & $0.80 \mathrm{ab}$ & $0.81 \mathrm{a}$ & $0.78 \mathrm{a}$ \\
\hline
\end{tabular}

${ }^{\mathrm{z}}$ Means with same lowercase letters within a row and harvest date are not significantly different among treatments by Tukey's honestly significant difference or (when all plants in one of the three treatments died) with a Student's $t$ test at $P<0.05$.

${ }^{y}$ All plants were dead.

Table 4. Leaf relative chlorophyll content $(\mathrm{SPAD})$ and transpiration $(\mathrm{E})$ of 10 ornamental taxa irrigated with nutrient solution [electrical conductivity $(\mathrm{EC})=1.2$ $\mathrm{dS} \cdot \mathrm{m}^{-1}$; Control] or saline solution $\left[\mathrm{EC}=5.0 \mathrm{dS} \cdot \mathrm{m}^{-1}(\mathrm{EC} 5)\right.$ or $10.0 \mathrm{dS} \cdot \mathrm{m}^{-1}$ (EC 10)] in a greenhouse. Plants were harvested after the fourth (first harvest, 5 weeks after initiation of treatment) and eighth treatment (second harvest, 9 weeks after initiation of treatment).

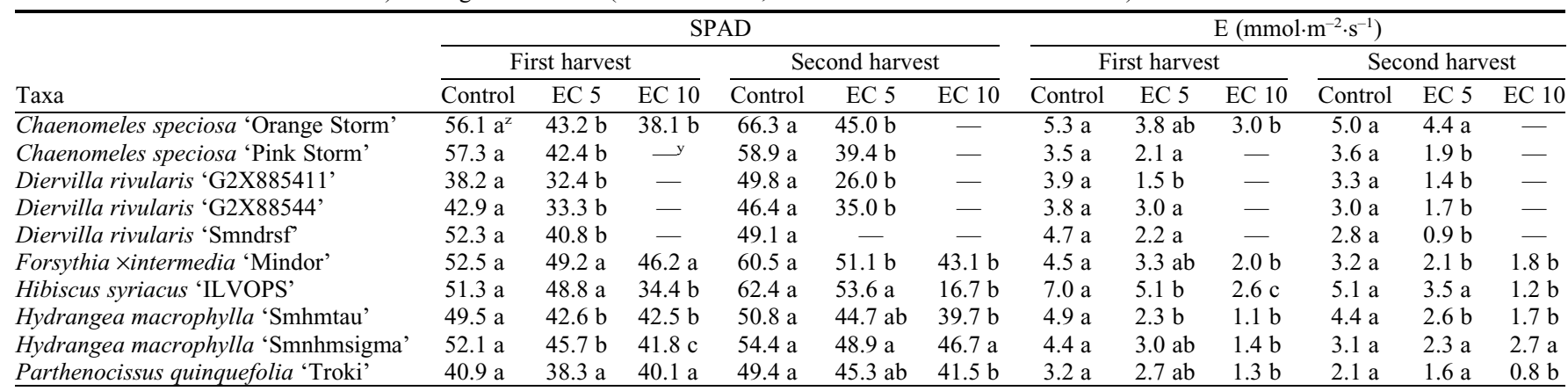

${ }^{\mathrm{z}}$ Means with same lowercase letters within a row and harvest date are not significantly different among treatments by Tukey's honestly significant difference or (when all plants in one of the three treatments died) with a Student's $t$ test at $P<0.05$.

${ }^{\mathrm{y}}$ All plants were dead.

Table 5. Leaf stomatal conductance $\left(g_{\mathrm{s}}\right)$ and net photosynthesis $\left(P_{\mathrm{n}}\right)$ of 10 ornamental taxa irrigated with nutrient solution [electrical conductivity $(\mathrm{EC})=1.2$ $\mathrm{dS} \cdot \mathrm{m}^{-1}$; Control] or saline solution [EC $=5.0 \mathrm{dS} \cdot \mathrm{m}^{-1}(\mathrm{EC} 5)$ or $\left.10.0 \mathrm{dS} \cdot \mathrm{m}^{-1}(\mathrm{EC} 10)\right]$ in a greenhouse. Plants were harvested after the fourth (first harvest, 5 weeks after initiation of treatment) and eighth treatment (second harvest, 9 weeks after initiation of treatment).

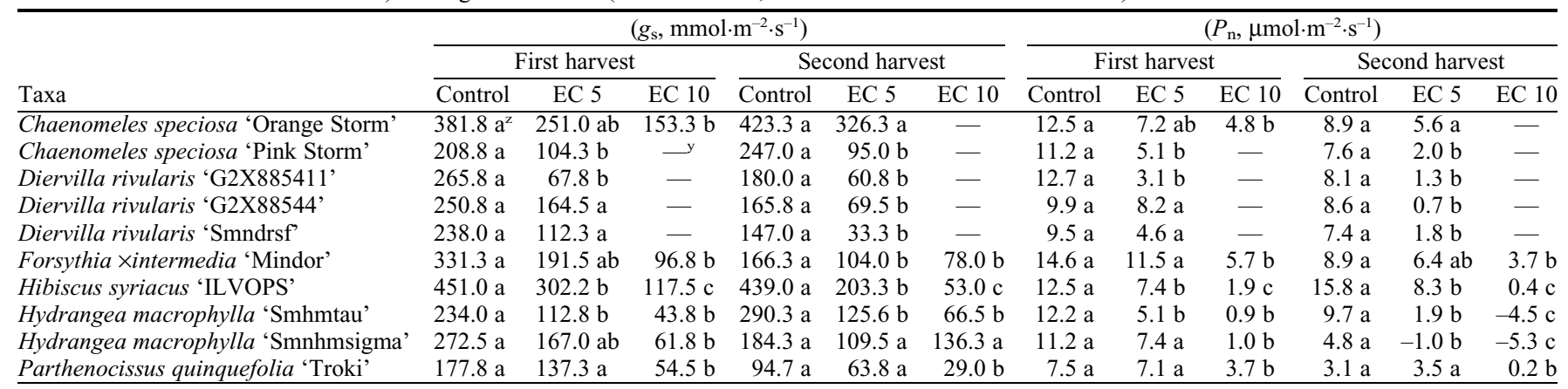

${ }^{\mathrm{z}}$ Means with same lowercase letters within a row and harvest date are not significantly different among treatments by Tukey's honestly significant difference or (when all plants in one of the three treatments died) with a Student's $t$ test at $P<0.05$.

${ }^{\mathrm{y}}$ All plants were dead.

H. macrophylla cultivars, and P. quinquefolia 'Troki' (Table 6), but elevated salinity increased $\mathrm{K}$ concentrations in C. speciosa 'Pink Storm'; D. rivularis 'G2X885411', 'G2X88544', and 'Smndrsf'; $F$. Xintermedia 'Mindor'; and H. syriacus 'ILVOPS'. Leaf $\mathrm{Ca}$ concentration in all taxa increased at elevated salinity (from 1.3 to 1.9 times in EC 5 and 1.4 to 2.3 times in EC 10). The highest $\mathrm{Ca}$ concentration $\left(44.6 \mathrm{mg} \cdot \mathrm{g}^{-1} \mathrm{DW}\right)$ was found in $H$ syriacus 'ILVOPS' in EC 10.

Generally, plants tolerate salt stress by avoiding uptake of $\mathrm{Na}$ and $\mathrm{Cl}$ ions or by tolerating high concentrations of these ions in the tissue (Munns and Tester, 2008). In this study, H. macrophylla plants had the highest leaf $\mathrm{Na}$ and $\mathrm{Cl}$ concentrations among all the tested taxa with acceptable visual quality, indicating that $H$. macro- phylla could tolerate high concentration of $\mathrm{Na}$ and $\mathrm{Cl}$. This phenomenon was also observed in Texas betony (Stachys coccinea), which survived in EC 10 with the highest leaf $\mathrm{Na}$ concentration $\left(56.8 \mathrm{mg} \cdot \mathrm{g}^{-1}\right.$ DW), and was identified as the most salttolerant taxa among the six investigated Lamiaceae ornamental species (Wu et al., 2016b). All C. speciosa and D. rivularis plants also had relatively high leaf $\mathrm{Na}$ and $\mathrm{Cl}$ 
Table 6. sodium $(\mathrm{Na})$, chloride $(\mathrm{Cl})$, pottasium $(\mathrm{K})$, and calcium $(\mathrm{Ca})$ concentrations of 10 ornamental taxa irrigated with nutrient solution [electrical conductivity $(E C)=1.2 \mathrm{dS} \cdot \mathrm{m}^{-1} ;$ Control] or saline solution $\left[\mathrm{EC}=5.0 \mathrm{dS} \cdot \mathrm{m}^{-1}(\mathrm{EC} 5)\right.$ or $10.0 \mathrm{dS} \cdot \mathrm{m}^{-1}$ (EC 10)] in a greenhouse. Plants were harvested after the fourth treatment ( 5 weeks after initiation of treatment).

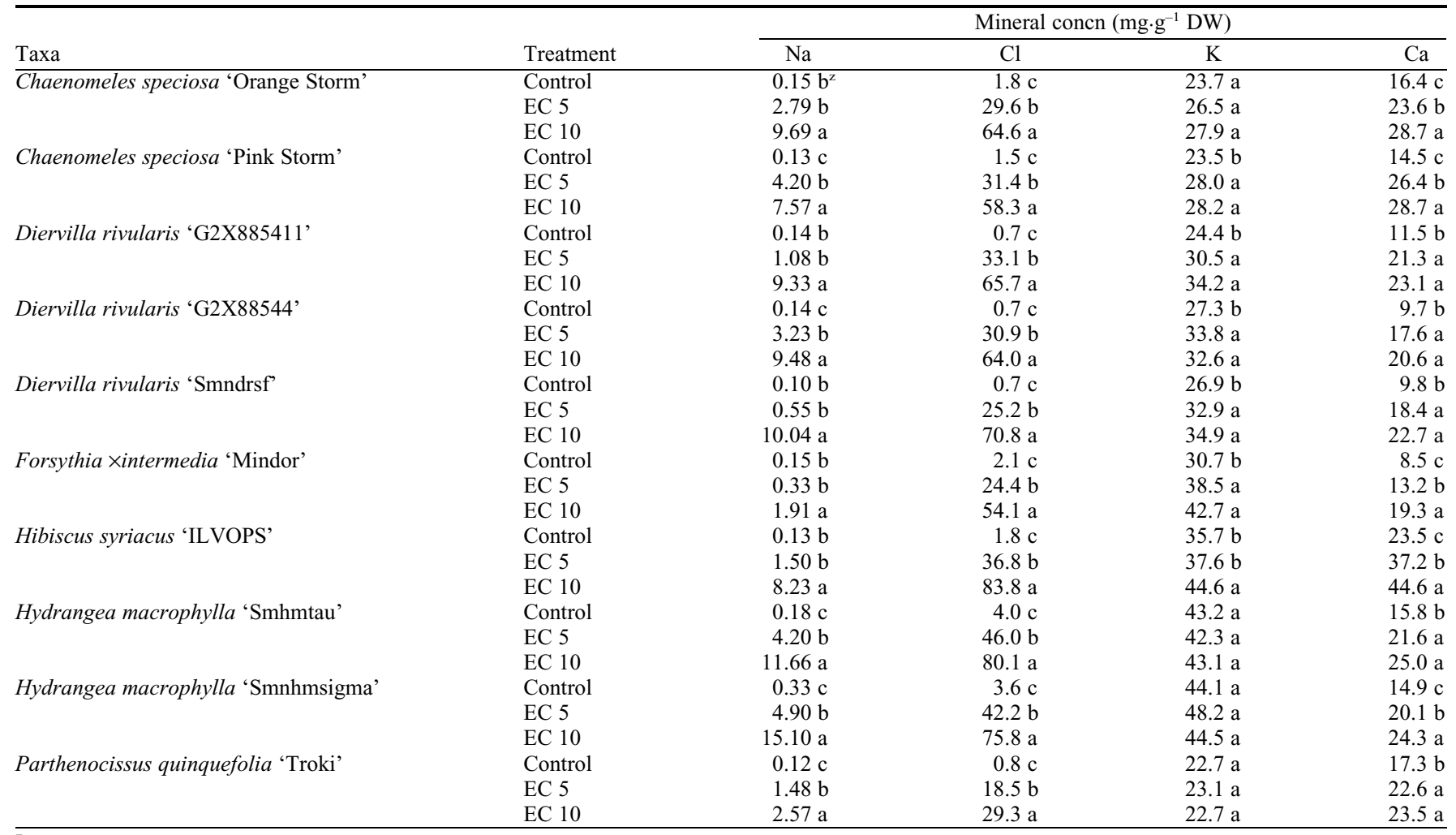

${ }^{\mathrm{z}}$ Means with same lowercase letters within a column and taxa are not significantly different by Tukey's honestly significant difference multiple comparison at $P<0.05$.

concentrations but exhibited severe foliar salt damage or died during the experiment, indicating low tolerance of $\mathrm{Na}$ and $\mathrm{Cl}$ accumulation and poor ability to exclude these ions from shoots. On the other hand, F. Xintermedia 'Mindor' and P. quinquefolia 'Troki' plants had relatively low leaf $\mathrm{Na}$ concentration at EC 10 and low $\mathrm{Cl}$ concentration at both EC 5 and EC 10 with acceptable visual quality. This suggests that the two taxa mentioned are able to restrict $\mathrm{Na}$ and $\mathrm{Cl}$ uptake and transport to shoots.

Maintenance of adequate $\mathrm{K}$ is essential for plant survival in saline environment (Grattan and Grieve, 1998). Although researchers reported a decline of $\mathrm{K}$ concentration in plant tissue when plants are exposed to high $\mathrm{Na}$ salinity, we did not observe any decrease in $\mathrm{K}$ concentration, rather an increase in some taxa, which may be caused by a strong $\mathrm{Na}$ concentration gradient (Grattan and Grieve, 1998). Wu et al. (2016a) observed that leaf $\mathrm{K}$ concentration increased significantly with increasing EC in Cuphea hyssopifolia. Sun et al. (2015) also observed that $\mathrm{K}$ level increased significantly with increasing EC in the leaves of Phlox paniculata 'John Fanick' and P. paniculata 'Texas Pink' plants.

Maintenance of adequate $\mathrm{Ca}$ is essential to prevent any negative impact on plant performance due to $\mathrm{Ca}$ deficiency, which occurs often even under nonsaline condi- tions. Factors which influence the availability of Ca to plants include the total Ca supply, the nature of counterions, substrate $\mathrm{pH}$, and the ratio of $\mathrm{Ca}$ to other cations in the substrate (Grattan and Grieve, 1998). In our study, $\mathrm{CaCl}_{2}$ was supplied as one of the salinizing agents in addition to $\mathrm{NaCl}$, which contributed to the increase in leaf $\mathrm{Ca}$ concentrations in all the taxa. Kaya and Higgs (2002) found that $\mathrm{Ca}\left(\mathrm{NO}_{3}\right)_{2}$ supplementation increased the yield and dry matter of cucumber in a soil high in $\mathrm{NaCl}$.

Cluster analysis. Salt-tolerant plants usually have less growth reduction and less foliar salt injury at elevated salinity (Cassaniti et al., 2009). For landscape plants, aesthetic appearance is more important than maximum growth. Therefore, assessment of salt tolerance for landscape plants should include aesthetic visual rating scores. A hierarchical cluster analysis was conducted based on relative values of height, DW, and visual score data. Ten ornamental taxa were separated into two distinguishable clusters in both EC 5 and EC 10 treatments (Fig. 2). All $C$. speciosa and D. rivularis plants were consistently clustered into group I in both EC 5 and EC 10 treatments and considered as the salt-sensitive plants. Forsythia $\times$ intermedia 'Mindor', H. macrophylla 'Smhmtau' and 'Smnhmsigma', and P. quinquefolia 'Troki' clustered into group II, representing the salttolerant group. Interestingly, $H$. syriacus 'ILVOPS' was classified as salt-tolerant taxa in EC 5 treatment, whereas it fell to saltsensitive group in EC 10 treatment. This might indicate that $H$. syriacus 'ILVOPS' is moderately salt tolerant. It can grow well in moderate salt levels (EC 5) without growth reduction, but cannot grow well at high salinity (EC 10) where only one of five plants survived after the eighth treatment.

In summary, the 10 ornamental taxa had different growth and physiological responses to salinity. Hydrangea macrophylla 'Smhmtau' and 'Smnhmsigma', $F$. Xintermedia 'Mindor', and $P$. quinquefolia 'Troki' were the most salt-tolerant taxa with minor foliar salt damage. Hydrangea macrophylla had the highest shoot $\mathrm{Na}$ and $\mathrm{Cl}$ concentrations with acceptable visual quality indicating that $H$. macrophylla plants were tolerant to high $\mathrm{Na}$ and $\mathrm{Cl}$ accumulation. Forsythia $\times$ intermedia 'Mindor' and P. quinquefolia 'Troki' had relatively low leaf $\mathrm{Na}$ and $\mathrm{Cl}$ concentration, suggesting that both taxa were able to exclude $\mathrm{Na}$ and $\mathrm{Cl}$. Hibiscus syriacus 'ILVOPS' was moderately salt tolerant with high leaf $\mathrm{Cl}$ concentrations, indicating that it may be sensitive to chloride-dominated salinity. Chaenomeles speciosa and D. rivularis were sensitive to salinity because of their greater growth reduction, foliar salt damage, and high $\mathrm{Na}$ and $\mathrm{Cl}$ accumulation in leaves. The results from this study may be used as a reference for selecting salt-tolerant plants for landscapes where poor quality water is used for irrigation. 

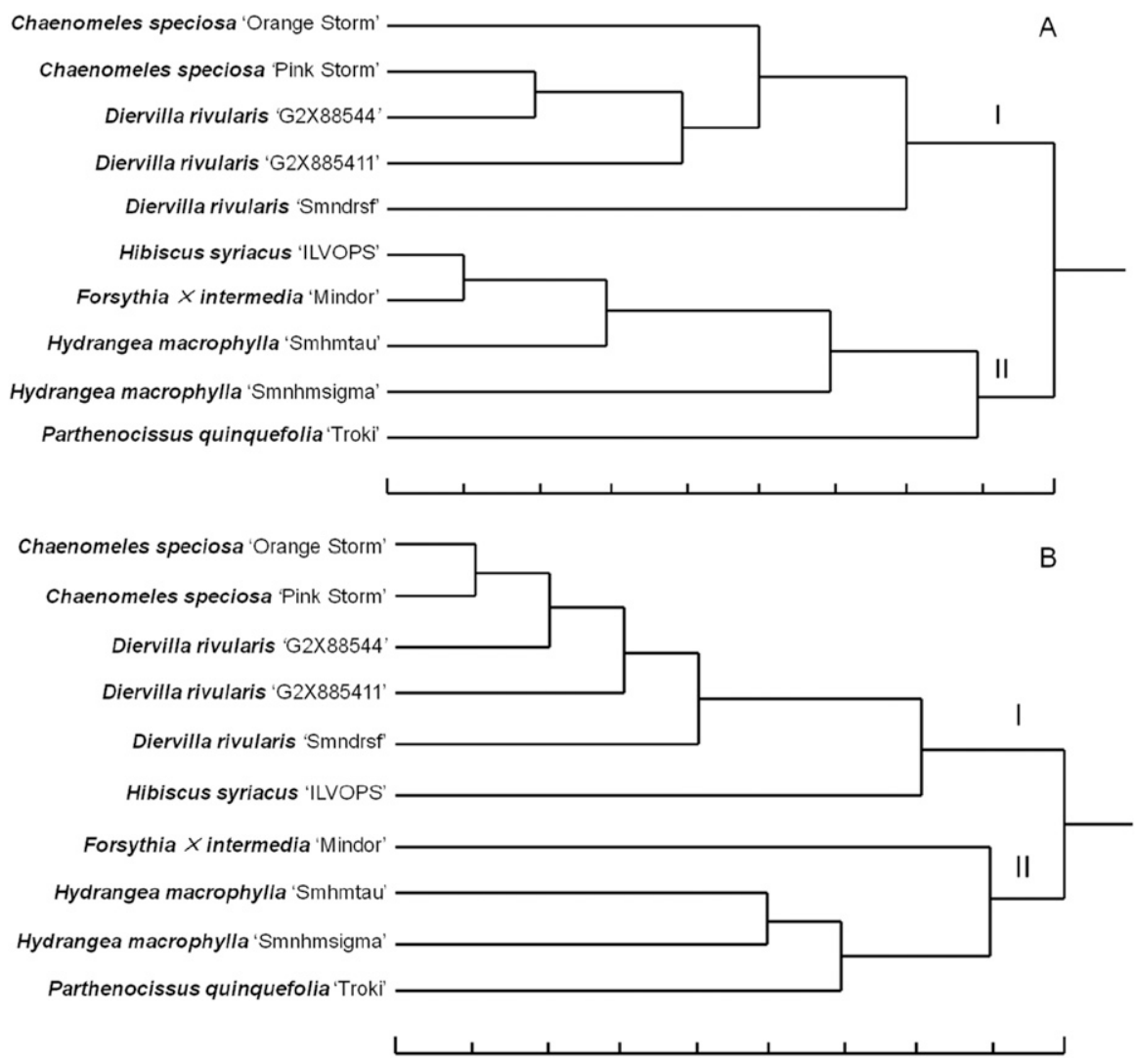

Fig. 2. Cluster analysis on the salt tolerance of 10 ornamental taxa according to the reduction of height, dry weight, and visual score as affected by elevated salinity at electrical conductivity of $5.0(\mathbf{A})$ and 10.0 $\mathrm{dS} \cdot \mathrm{m}^{-1}(\mathbf{B})$.

\section{Literature Cited}

Altland, J.E., J.C. Locke, and C.R. Krause. 2014. Influence of pine bark particle size and $\mathrm{pH}$ on cation exchange capacity. HortTechnology 24:554-559.

Bernstein, N., B.T. Asher, F. Haya, S. Pini, R. Ilona, C. Amram, and I. Marina. 2006. Application of treated wastewater for cultivation of roses (Rosa hybrida) in soil-less culture. Scientia Hort. 108:185-193.

Cabrera, R.I. 2009. Revisiting the salt tolerance of crape myrtles (Lagerstroemia spp.). Arboricult. Urban For. 35:129-134.

Cai, X., Y. Sun, T. Starman, C. Hall, and G. Niu. 2014. Response of 18 Earth-Kind ${ }^{\circledR}$ rose cultivars to salt stress. HortScience 49:544-549.

Cassaniti, C., C. Leonardi, and T.J. Flowers. 2009. The effects of sodium chloride on ornamental shrubs. HortScience 122:586-593.

Cavins, T.J., B.E. Whipker, and W.C. Fonteno. 2008. Pourthru: A method for monitoring nutrition in the greenhouse. Acta Hort. 779:289-297.

Dobrowolski, J., M. O’Neill, L. Duriancik, and J. Throwe. 2008. Opportunities and challenges in agricultural water reuse: Final report. USDACSREES.

Gavlak, R.G., D.A. Horneck, and R.O. Miller. 1994. Plant, soil, and water reference methods for the western region. Western Regional Extension Publication (WREP) 125.

Grattan, S.R. and C.M. Grieve. 1998. Salinitymineral nutrient relations in horticultural crops. Scientia Hort. 78:127-157.

Havlin, J.L. and P.N. Soltanpour. 1989. A nitric acid and plant digest method for use with inductively coupled plasma spectrometry. Commun. Soil Sci. Plant Anal. 14:969-980.

Isaac, R.A. and W.C. Johnson. 1975. Collaborative study of wet and dry ashing techniques for the elemental analysis of plant tissue by atomic absorption spectrophotometry. J. Assn. Offic. Anal. Chem. 58:436-440.

Kaya, C. and D. Higgs. 2002. Calcium nitrate as a remedy for salt-stressed cucumber plants. J. Plant Nutr. 25:861-871.

LeCompte, J.S., A.N. Wright, C.M. LeBleu, and J.R. Kessler. 2017. Saline irrigation affects growth and leaf tissue nutrient concentration of three native landscape plant species. HortTechnology 26:309-313.

Lu, C., N. Qiu, B. Wang, and J. Zhang. 2003. Salinity treatment shows no effects on photosystem II photochemistry, but increases the resistance of photosystem II to heat stress in halophyte Suaeda salsa. J. Expt. Bot. 54:851860.

Morgan, K.T., T.A. Wheaton, L.R. Parsons, and W.S. Castle. 2008. Effects of reclaimed mu- nicipal waste water on horticultural characteristics, fruit quality, and soil and leaf mineral concentration of citrus. HortScience 43:459 464.

Munns, R. 2002. Comparative physiology of salt and water stress. Plant Cell Environ. 25:239250.

Munns, R. and M. Tester. 2008. Mechanisms of salinity tolerance. Annu. Rev. Plant Biol. 59:651-681.

Niu, G. and R.I. Cabrera. 2010. Growth and physiological responses of landscape plants to saline water irrigation: A review. HortScience 45:1605-1609.

Niu, G. and D.S. Rodriguez. 2006. Relative salt tolerance of five herbaceous perennials. HortScience 41:1493-1497.

Niu, G., D.S. Rodriguez, and L. Aguiniga. 2007. Growth and landscape performance of ten herbaceous species in response to saline water irrigation. J. Environ. Hort. 25:204-210.

Niu, G., D.S. Rodriguez, and C. McKenney. 2012. Response of selected wildflower species to saline water irrigation. HortScience 47:13511355.

Percival, G.C. 2005. Identification of foliar salt tolerance of woody perennials using chlorophyll fluorescence. HortScience 40:18921897.

Sixto, H., I. Aranda, and J.M. Grau. 2006. Assessment of salt tolerance in Populus alba clones using chlorophyll fluorescence. Photosynthetica 44:169-173.

Sun, Y., G. Niu, and C. Perez. 2015. Relative salt tolerance of seven texas superstar ${ }^{\circledR}$ perennials. HortScience 50:1562-1566.

Tanji, K., S. Grattan, C. Grieve, A. Harivandi, L. Rollins, D. Shaw, B. Sheikh, and L. Wu. 2008 A comprehensive literature review on salt management guide for landscape irrigation with recycled water in coastal southern California. 10 Aug. 2017. <www.salinitymanagement.org>. $320 \mathrm{p}$.

Tattini, M., G. Montagni, and M.L. Traversi. 2002. Gas exchange, water relations and osmotic adjustment in Phillyrea latifolia grown at various salinity concentrations. Tree Physiol. 22:403-412.

Wright, R.D. 1986. The pour-through nutrient extraction procedure. HortScience 21:227-229.

Wu, S., Y. Sun, and G. Niu. 2016a. Morphological and physiological responses of nine ornamental species to saline irrigation water. HortScience $51: 285-290$

Wu, S., Y. Sun, G. Niu, L.G.P. Graciela, and C.R. Arturo. 2016b. Responses of six Lamiaceae landscape species to saline water. J. Environ. Hort. 34:30-35.

Yeager, T.H., J.K. von Merveldt, and C.C. Larsen. 2010. Ornamental plant response to percentage of reclaimed water irrigation. HortScience 45:1610-1615.

Zeng, L., M.C. Shannon, and C.M. Grieve. 2002. Evaluation of salt tolerance in rice genotypes by multiples agronomic parameters. Euphytica 127:235-245.

Zollinger, N., R. Koenig, T. Cerny-Koenig, and R. Kjelgren. 2007. Relative salinity tolerance of intermountain western United States native herbaceous perennials. HortScience 42: 529-534. 